\title{
腎孟尿管腫瘍に併発する膀胱腫瘍の臨床的検討
}

\author{
山形県立中央病院泌尿器科 (主任：加藤弘彰)

$\begin{array}{llll}\text { 菅野 理 } & \text { 庄司 } & \text { 則文 堀米 亨 } \\ \text { 内 啓一郎 } & \text { 加藤 } & \text { 弘彰 } & \end{array}$

\section{A CLINICAL STUDY OF ASSOCIATED BLADDER TUMOR IN PATIENTS WITH RENAL PELVIC AND URETERAL TUMOR}

\author{
Osamu Sugano, Norifumi Shouji, Tooru Horigome, \\ Keiichirou Uchi and Hiroaki Katou \\ Department of Urology, Yamagata Prefectural Central Hospital
}

We investigated the incidence of associated bladder tumor and prognosis in 101 cases with a pathological diagnosis of transitional cell carcinoma, selected from those with renal pelvic and ureteral tumor whom we had encountered over the 18 years between April 1976 and March 1993. Among these 101 cases, the incidence of associated bladder tumor was noted in 42 (41.6\%), 23 (22. $8 \%$ ) with coexistence and $19(18.8 \%)$ with subsequence. As for the primary site of renal pelvis and ureter, the coexistence was $15.4 \%$ and subsequence $20.5 \%$ in renal pelvis, and the coexistence was $24.6 \%$ and subsequence $19.3 \%$ in ureter, and the coexistence was $60.0 \%$ and subsequence $0.0 \%$ in both renal pelvis and ureter. The incidence of coexistent bladder tumor was high in both renal pelvis and ureter, but no significant difference was noted. As for the stage, the incidence of coexistence was high in $T_{1}$, while subsequence was high in $T_{2}$, but no significant difference was noted. As for the grade, the incidence of coexistence was high in $\mathrm{G}_{2}$, but no significant difference was noted. The 5 year survival rate was $58.2 \%$ in those without, $54.2 \%$ with coexistence, and 82 . $5 \%$ with subsequent bladder tumor, with a significant difference $(\mathrm{p}<0.05)$ between the last two groups. The interval of subsequent bladder tumor ranged from 4 to 164 months (mean 27.7 months), with the incidence within 2 years being approximately $70.0 \%$.

It was found that the renal pelvic and ureteral tumors are frequently associated bladder tumor while associated bladder tumor dose not appear to have an ill effect on the prognosis. Therefore it is necessary that patients with renal pelvic and ureteral tumor be observed closely for 5 years, especially for the initial 2 years.

Key words: renal pelvic and ureteral tumor, associated bladder tumor, prognosis

要旨：1976年 4 月から1993年 3 月までの18年間に経験した腎孟尿管腫瘍のうち, 病理組織学的に移行上 皮癌と診断された101例を対象に併発膀胱腫瘍の発生頻度と予後について検討した.膀胱腫瘍先行例は除 外した。

101例中，同時性23例（22.8\%)，続発性19例（18.8\%）計42例（41.6\%）に併発がみられた。腎孟尿 管腫瘍の部位別では，腎盂が同時性 $15.4 \%$ ，続発性 $20.5 \%$ ，尿管が同時性 $24.6 \%$ ，続発性 $19.3 \%$ ，腎孟 尿管多発が同時性 $60.0 \%$ ，続発性 $0.0 \%$ と腎孟尿管多発例に同時性併発が多い傾向があるが有意差はな かった。病期との関係では T1に同時性, T2に続発性併発が多いが有意差はなかった。異型度との関係で は G2に併発が多いが有意差はなかった。併発膀胱腫痬別 5 年生存率は併発なし $59.3 \%$, 同時性 $54.2 \%$, 続発性 $82.5 \%$ で同時性と続発性の間に有意差 $(\mathrm{p}<0.05)$ があった。膀胱腫瘍発性までの期間は 4 力月か ら164力月, 平均 27.7 月, 2 年以内の発生が約70\%であった。

腎孟尿管腫瘍は高率に膀胱腫瘍を併発するが，併発膀胱腫瘍は予後にそれほど悪影響は与えていない 
ので術後 5 年間, 特に 2 年間は膀胱腫湯の併発に注意して経過観察する必要がある.

キーワード：腎孟尿管腫瘍, 併発膀胱腫瘍, 予後

\section{緒言}

腎孟尿管腫場は高率に膀胱腫瘍を併発し予後不良と されている。そこで併発膀胱腫湯の発生頻度および予 後について検討した.

\section{対象と方法}

1976年 4 月から 1993 年 3 月までの18年間に当科で経 験した腎孟尿管腫瘍のうち病理組織学的に移行上皮癌 と診断された101例を対象とした.膀羘腫場先行例は除 外した。

性別は男性69人，女性32人で男女比は約 $2 ： 1$ で あった。年齢は男性37歳から84歳, 女性43歳から83歳, 平均67歳であった。患側は右側49例, 左側51例, 両側 1 例であった。腎孟尿管腫瘍の部位は腎孟39例，尿管 57例，腎孟尿管多発 5 例であった．腎盂尿管腫瘍の病 期と異型度は表 1 のごとくであった。

初回治療法は, 腎尿管全摘出兼膀胱部分切除術が 66 例, 腎尿管膀胱全摘出術が 7 例, 尿管部分切除術が 8 例, 腎尿管摘出術が 7 例, 腎摘出術が 5 例, 試験開腹 術が 4 例, TUR-Bt が 2 例, 膀胱全摘出術が 1 例, 腎 瘦術が 1 例であった。

初回治療時に膀胱腫瘍が同時に存在したものを同時 性, 腎孟尿管腫瘍の経過観察中に膀胱腫瘍が発生した ものを続発性とした. 腎孟尿管腫瘍の部位別, 病期別, 異型度別に併発膀胱腫瘍の発生頻度と 5 年生存率につ いて検討した。続発性膀胱腫瘍については初回再発時 期と治療法について検討した。観察期間は 1 カ月から 207カ月, 平均56.8力月であった.

生存率の算定は Kaplan-Meier 法で行い, 生存率の 検定は Generalized-Wilcoxon 法で行った？その他の 検定は $\chi$ 二乗検定で行った。

\section{結果}

（1）腎孟尿管腫湯101例中，同時性23例（22.8\%),

表 1 腎盂尿管腫瘍の病期と異型度. 腎孟尿管腫瘍の 病期と異型度の関係を示す

\begin{tabular}{r|r|r|r|r|r|c}
\hline & Ta & T1 & T2 & T3 & T4 & \\
\hline G1 & 8 & 2 & 1 & 1 & 0 & 12 \\
G2 & 15 & 10 & 10 & 10 & 3 & 48 \\
G3 & 3 & 8 & 4 & 18 & 8 & 41 \\
\hline & 26 & 20 & 15 & 29 & 11 & 101 例 \\
\hline
\end{tabular}

続発性19例（18.8\%）の計42例（41.6\%）に膀胱腫瘍 が併発した。経過中に膀胱腫瘍の発生をみなかったの は59例（58.4\%）であった。

（2）腫瘍の部位と併発膀胱腫瘍の関係は，併発有り が腎孟では14例 (35.9\%)，尿管では25例 (43.9\%)， 腎孟尿管多発では 3 例 $(60.0 \%)$ と同時性併発が腎盂 尿管多発例に多い傾向があるが有意差は認められな かった（表 2).

（3）病期と併発膀胱腫瘍の関係は, T1に最も多く, 次いで T2，Ta，T4，T3の順で T1に同時性，T2に続 発性併発が多いが有意差はなかった（表 3 ).

（4）異型度と併発膀脂腫瘍の関係は，Grade 2に続

表 2 腫場部位と併発膀胱腫瘍。腎孟尿管腫場の部位 と併発膀胱腫瘍の関係を示す

\begin{tabular}{c|c|c|c|c}
\hline & 腎孟 & 尿管 & 腎孟+尿管 & \\
\hline 併発なし & 25 & 32 & 2 & 59 \\
& $(64.1 \%)$ & $(56.1 \%)$ & $(40.0 \%)$ & \\
同 時 性 & 6 & 14 & 3 & 23 \\
& $(15.4 \%)$ & $(24.6 \%)$ & $(60.0 \%)$ & \\
続 発 性 & 8 & 11 & 0 & 19 \\
\hline & 39 & 57 & 5 & 101 例 \\
\hline
\end{tabular}

表 3 病期と併発膀胱腫瘍. 腎孟尿管腫瘍の病期と併 発膀胱腫瘍の関係を示す

\begin{tabular}{l|c|c|c|c|c|c}
\hline & $\mathrm{Ta}$ & $\mathrm{T} 1$ & $\mathrm{~T} 2$ & $\mathrm{~T} 3$ & $\mathrm{~T} 4$ & \\
\hline 併発なし & 16 & 8 & 8 & 20 & 7 & 59 \\
(61.5\%) & $(40.0 \%)$ & $(53.3 \%)$ & $(69.0 \%)$ & $(63.6 \%)$ & \\
5 & 7 & 2 & 6 & 3 & 23 \\
同 時 性 & $(19.2 \%)$ & $(35.0 \%)$ & $(13.3 \%)$ & $(20.7 \%)$ & $(27.3 \%)$ & \\
5 & 5 & 5 & 3 & 1 & 19 \\
続 発性 & $(19.1 \%)$ & $(25.0 \%)$ & $(33.3 \%)$ & $(10.3 \%)$ & $(9.1 \%)$ & \\
\hline & 26 & 20 & 15 & 29 & 11 & 101 例 \\
\hline
\end{tabular}

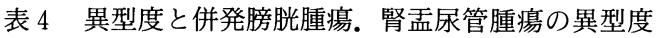
と併発膀胱腫瘍の関係を示す

\begin{tabular}{c|c|c|c|c}
\hline & $\mathrm{G} 1$ & $\mathrm{G} 2$ & $\mathrm{G} 3$ & \\
\hline 併発なし & 9 & 25 & 25 & 59 \\
& $(75.0 \%)$ & $(52.1 \%)$ & $(61.0 \%)$ & \\
同 時性 & $\begin{array}{c}2 \\
(16.7 \%)\end{array}$ & $\begin{array}{c}11 \\
(22.9 \%)\end{array}$ & $\begin{array}{c}10 \\
12\end{array}$ & 23 \\
続 発 性 & $(8.3 \%)$ & $(25.0 \%)$ & $(14.6 \%)$ & 19 \\
\hline & 12 & 48 & 41 & 101 例 \\
\hline
\end{tabular}


発性併発が多く,Grade 3に同時性併発が多いが有意 差はなかった（表 4 ).

（5）併発膀胱腫湯別 5 年生存率は,併発なし $59.3 \%$, 同時性 $54.2 \%$, 続発性 $82.5 \%$ と続発性が最も良く同時 性との間に有意差（p<0.05）が認められた（図 1$)$.

（6）続発性および同時性で初回治療時に膀胱を温存 した15例のうち膀胱再発をみた 8 例を含む 27 例の膀胱 腫湯発生までの期間は 4 力月から164力月, 平均 27.7 力 月で約 $70 \%$ は 2 年以内だが， 5 年間は膀胱腫崵の発生 が多かった（図 2 ）。

（7）膀胱腫瘍が発生した27例中23例（85\%）は表在 性膀胱腫瘍の時期に発見され，1例を除き膀胱温存療 法が行われた。表在性膀羘腫瘍の時期に発見されたに もかかわらず腎尿管膀胱全摘出後が行われたのは，心

図 1 併発膀腅腫崵別生存率

同時性と続発性の間に有意差（ $\mathrm{p}<0.05 ）$ がある.

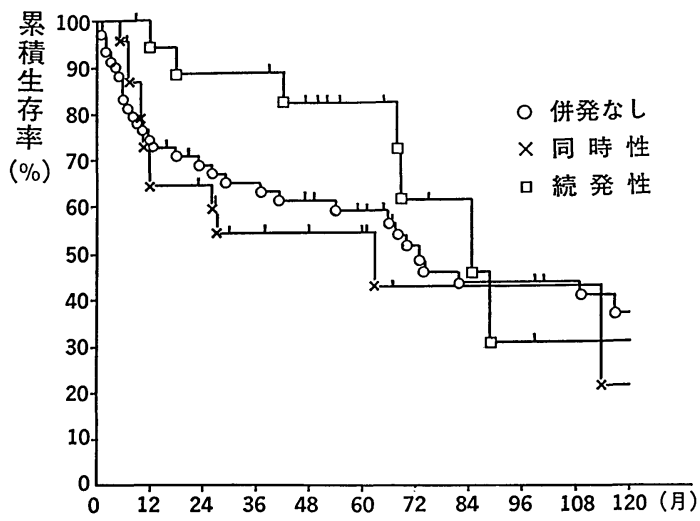

図 2 膀胱腫瘍非併発曲線

続発性および同時性で初回治療時に膀胱を温存した症 例の膀胱腫瘍非併発曲線。

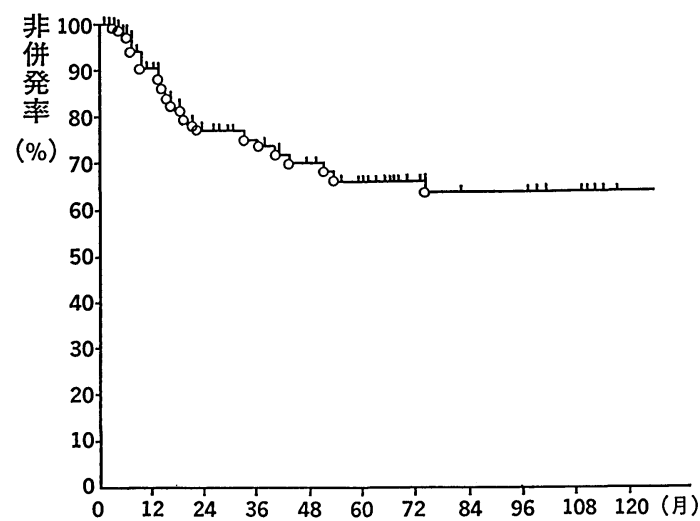

表 5 続発性膀胱腫瘍の病期と治療法. 続発性および 同時性で初回治療時に膀胱を温存し膀胱再発をみた 症例の膀胱腫瘍の病期と治療法を示す

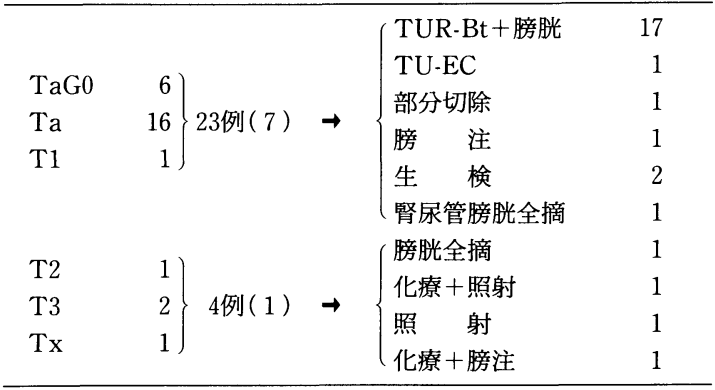

（）内は同時性で再発をみた症例

筋梗塞を併発し治療が遅れた症例である.T2は小腫瘍 だが浸潤癌に進行していた例，T3は自己中断 1 例, 肺 転移 1 例， Tx は高齢のため検査しなかった 1 例で あった(表 5 ).

\section{考 察}

腎孟尿管腫瘍は近年増加しているものの，同じ尿路 上皮である膀胱腫瘍に比較して頻度は少なく，まだ多

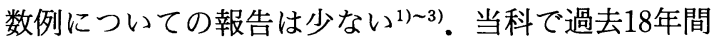
に経験した腎孟尿管腫瘍のうち病理組織学的に移行上 皮癌と診断されたのが101人で平均年間発生率は 5.6 人/年となり，同時期の膀胱腫瘍の約 $23 \%$ であった。

腎孟尿管腫瘍は膀胱腫瘍を併発する事が多く，本邦 では $20.5 \%$ ４6.1\% ${ }^{45)}$ と報告されている. 自験例でも 諸家の報告と同様に，101例中同時性23例 (22.8\%), 続発性19例 (18.8\%)，計42例 (41.6\%) に膀胱腫瘍の 併発をみた。

腎盂尿管腫瘍の部位と併発膀胱腫瘍との関係につい て, 大矢ら ${ }^{6)}$ の腫瘍部位と併発頻度に有意差はなかっ たとの報告もあるが，田代ら ${ }^{2)}$ は腎孟尿管多発例で有 意に併発膀胱腫瘍が多いと報告しているように，腎孟 尿管多発例に併発が多いとする報告が多い. 自験例で も統計学的に有意差は認められなかったが，腎孟尿管 多発例に同時性併発が多く，腎盂に少ない傾向が認め られた。このことは尿路腫瘍の多中心性発生を示唆す るものと考えられる。

病期と併発膀胱腫瘍の関係について，松木ら ${ }^{7}$ は high grade, high stage 例に併発膀胱腫瘍が多かった と報告, 田代ら ${ }^{2)}$ は T4が併発膀胱腫湯の頻度が低い傾 向がみられたが，他の病期と併発には何の関連もな かったと報告している，自験例では，統計学的に有意 
差は認められないが，T1，T2に併発が多く，T3，T4 に続発性併発が少なかった。このことは病期が進行し た症例では膀胱腫瘍を併発する前に死亡することが多 く, Ta では implantation が起こる前に根治療法が行 われたためと推測される。

異型度と併発膀胱腫瘍の関係について，田代ら ${ }^{2)}$ G1で続発性に, G3で初発及び続発性発生が若干高いが 有意差はなかったと報告している. 自験例では統計学 的に有意差は認められないが，同時性併発は異型度に 比例し, 続発性併発は G2に多かった。同時性併発頻度 が各異型度間で差が少ないのは, 腎盂尿管と膀胱の異 型度が同じ症例が多いことからみても尿路腫瘍の多中 心発生を示唆するものと考えられる. 続発性併発が G2 に多いのは, G1は表在性腫瘍が多く早期に根治療法が 行われ，G3は進行例が多く予後不良なためと考えられ る.

腎孟尿管腫瘍の 5 年生存率は $19 \%$ ～ $68 \%$ まであるが

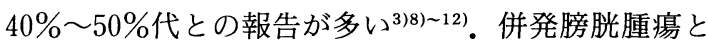
予後について, 富樫ら ${ }^{5)}$ は併発群が予後良好と報告, 多 田ら ${ }^{1)}$, 田代 ${ }^{21}$ は併発と予後に有意差はなかったと報 告, 松木ら していない. 自験例の 5 年累積生存率は全体で $62.4 \%$, 併発なし $59.3 \%$ ，同時性 $54.2 \%$, 続発性 $82.5 \%$ と同時 性と続発性の間に有意差が認められた（ $\mathrm{p}<0.05)$. 続 発性が予後良好な理由としては, High grade, High stage 症例が少ないこと, 術後経過観察が良く行われ 早期に膀胱腫瘍が発見されていることや，前癌状態が 長く続く症例が含まれていることなどが考えられる. 前癌状態について, Kakizoe ら ${ }^{13)}$ は12例の腎孟尿管腫 瘍症例を詳細に検討し，全例に腫瘍近接部や遠隔部に 前癌状態を認めたと報告している，当科では膀胱腫瘍 同時併発例以外は原則として膀胱生検は行っていない ので，前癌状態の有無については検討できないが，3 例でそれぞれ 6 力月，16力月，18力月後に顕性癌に進 展した症例を経験したことから, 前癌状態が比較的長 く続く症例があるものと推測される.

膀脂腫場再発までの期間については 2 年以内に多い と報告されている(25)7)11). 自験例における再発までの 期間は 4 力月から 164 力月, 平均 27.7 力で約 $70 \%$ 2 年以内の再発で諸家の報告と同様である。しかし，そ の後も再発がみられるので, 術後 5 年間は注意して経 過観察をする必要があると考えている．当科では原則 として術後 2 年間は 3 カ月毎, その後 5 年までは 4 〜 6 力月ごとに検查を行い， 5 年経過後も年 $1 \sim 2$ 回
は受診するように指導している。

膀胱腫瘍の再発予防を目的に抗癌剤や BCG の予防 的膀胱内注入療法が試みられている ${ }^{14115)}$. 自験例に於 ける膀胱腫瘍の再発が続発性で $18.8 \%$ ，時性では 53.3\%あり，われわれは同時性かつ表在性の症例が再 発予防治療の適応と考元，1988年以降，抗癌剤の膀胱 内注入療法を行っている.

\section{結 語}

1）組織学的に移行上皮癌と診断された原発性腎盂 尿管腫瘍101例中 23 例 (22.8\%) に同時性, 19例 (18.8\%) に続発性膀羘腫瘍の併発を認めた。

2）腫湟部位別では腎孟尿管多発例に同時性併発が 多い傾向がみられ，病期別では T1に，異型度別では G2に併発膀胱腫瘍が多いが有意差はなかった。

3） 5 年生存率は併発なし $59.3 \%$, 同時性 $54.2 \%$, 続 発性 $82.5 \%$ で同時性と続発性の間に有意差があった $(\mathrm{p}<0.05)$.

4）膀胱腫瘍発生までの期間は 4 力月から 164 力月, 平均 27.7 月で, 約70\%は 2 年以内であった.

5）腎孟尿管腫瘍に併発する膀胱腫瘍は予後に悪影 響を与えないが，併発に注意して経過観察をする必要 がある。

本論文の要旨は, 第82回日本泌尿器科学会総会（福岡, 1994）において発表した。

\section{文献}

1) 多田安温, 中野悦次, 藤岡秀樹, 松田 稔, 高羽 津, 園田孝夫, 長船匡男：腎孟尿管腫崵102例の臨 床的検討. 日泌尿会誌，77，507-516，1986。

2）田代和也, 古田 希, 岩室紳也, 小針俊彦, 浅野晃 司, 中内憲二, 長谷川倫男, 和田鉄郎, 大石幸彦, 町田豊平：腎孟尿管癌に併発する膀胱癌の臨床的 意義. 日泌尿会誌，82，1771-1775，1991.

3）栗山 学, 小幡浩司, 林 秀治, 島谷政佑, 加藤次 朗, 小野佳成, 朴木繁博, 加藤雅史, 米田勝紀, 増 田宏昭, 北川元昭, 中野 優: 腎盂尿管腫崵の臨床 的検討。日泌尿会誌，84，1839-1844，1993.

4）竹原 朗, 蓮井良浩, 山口孝則, 西 昇平, 長田幸 夫：腎孟尿管腫瘍39例の臨床病理学的検討. 西日 泌尿，52，14-20，1990.

5）富樫正樹, 豊田健一, 柏木 明, 浅野嘉文, 永森 聡, 関 利盛, 小柳知彦, 丸 彰夫: 腎孟尿管腫瘍 に併発する膀腅腫湟の臨床的検討. 泌尿紀要, 36, 1141-1147, 1990.

6) 大矢 晃, 高橋徳男, 網野洋一郎, 染野 敬: 腎孟 尿管腫瘍に伴った膀胱腫崵の臨床的検討. 西日泌 尿, 50, 1175-1177, 1988.

7）松木 尚, 大園誠一郎, 谷 善啓, 黒岡公雄, 辻本 
賀洋, 藤本清秀, 百瀬 均, 金子佳照, 吉田克法, 岡本新司, 佐々木憲二, 丸山良夫, 平尾佳彦, 岡島 英五郎：膀脱腫瘍の併発がみられた腎孟・尿管腫 瘍症例の検討。泌尿紀要，35，239-246，1989.

8）川島清隆, 橋本勝善, 登丸行雄, 北浦宏一, 鈴木孝 憲, 今井強一, 山中英寿：腎孟尿管癌の予後因子の 検討. 西日泌尿，54，1703-1708，1992.

9）上田陽彦, 岡田茂樹, 和泉 孝, 大西周平, 西本和 彦, 川崎利博, 大原裕彦, 楖原敏彦, 砺波博一, 神 原朱実, 井上裕之, 青山直樹, 浜田勝生, 高崎 登, 宮崎 重：腎孟・尿管腫湯の臨床的観察。泌尿紀 要, 34, 1161-1171, 1988.

10）長井辰哉, 高士宗久, 坂田孝雄, 高村真一, 岡村菊 夫, 金井 茂, 佐藤正文, 下地敏雄, 三宅弘治：腎 孟尿管腫崵の統計学的検討. 日泌尿会誌, 81, 447 $-453,1990$.

11）山下朱生, 山下元幸, 亀井義広, 藤田幸利：腎孟尿 管腫場の臨床的検討. 西日泌尿, 51，1157-1163,
1989.

12）西村和郎, 今津哲央, 坂上和弘, 吉村一宏, 三好 進, 水谷修太郎: 腎孟尿管腫瑒の臨床的観察. 泌尿 紀要，38，1009-1013，1992.

13) Kakizoe, T., Fujita, J., Murase, T., Matsumoto, K. and Kisi, K.: Transitional cell carcinoma of the bladder in patients with renal pelvic and ureteral cancer. J. Urol., 124, 17-19, 1980.

14）田利清信, 佐竹一郎, 児島真一, 根岸壮治, 吉田謙 一郎，中目康彦，金親史尚，堀内 晋，斉藤 隆， 大和田文雄, 野呂 彰: 制癌剤膀腅内注入療法に よる腎孟・尿管腫崵術後の膀胱腫崵発生予防効果. 泌尿紀要，33，852-856，1987.

15）工藤達也, 本村文一, 斉藤文匡, 古川利有, 鈴木唯 司：BCG 膀胱内注入による腎孟尿管腫崵術後の 膀脱内再発予防効果. 日泌尿会誌, 81, 1857-1860, 1990.

（1994年12月1日受付，1995年4月6日受理） 